УДК 338.1

DOI: https://doi.org/10.32851/2708-0366/2021.8.4

Капліна A.I.

кандидат економічних наук, доцент кафредри менеджменту та інформаційних технологій, Херсонський державний аграрно-економічний університет ORCID: https://orcid.org/0000-0001-6714-797X

Kaplina Anastasiia

Kherson State Agrarian and Economic University

\title{
МОЛОДІЖНЕ ПІДПРИєМНИЦТВО ЯК ЧИННИК РОЗВИТКУ ЕКОНОМІКИ
}

\section{YOUTH ENTREPRENEURSHIP AS A FACTOR IN ECONOMIC DEVELOPMENT}

Діяльність у галузі молодіжного підприємництва спрямоване на вирішення проблем, перш за все, сочіально-економічного характеру: зниження рівня безробіття, реалізація можливості створення нових робочих місцьь, розвиток нових напрямів та галузей економіки тощцо. Молодіжне підприємництво - один з факторів розвитку економіки краӥни, тому має місие необхідність залучення молоді до підприємництва. У статті наведена сучасна наукова практика молодіжного підприємництва, яка виокремила окремі його ознаки, а також визначила ряд сильних та слабких сторін даного феномену. На основі аналізу представлено ретроспективу позичіонування молоді в сучасній бізнес-спільноті та сформульовано найважливіші напрями вдосконалення изього перспективного вектору національної молодіжної політики. Автор проаналізував вітчизняний та зарубіжний досвід форм і методів підтримки та розвитку молодіжного підприємництва, висвітив основні формати.

Ключові слова: молодь, малий бізнес, культура, бізнес-інічіативи, розвиток молодіжного підприємництва, проблеми ведення бізнесу.

Деятельность в сфере молодежного предпринимательства направлена на решение проблем, прежде всего, социально-экономического характера: снижение безработицы, реализация возможности создания новых рабочих мест, развитие новых направлений $и$ отраслей экономики и др. Молодежное предпринимательство является одним из факторов развития экономики страны, поэтому возникает необходимость привлечения молодежи к предпринимательству. В статье представлена современная научная практика молодежного предпринимательства, в которой выделены некоторые его особенности, а также вылялен ряд сильных и слабых сторон данного явления. На основе анализа представлена ретроспектива позиционирования молодежи в современном бизнес-сообществе и сформулированы важнейшие направления совериенствования этого перспективного вектора национальной молодежной политики. Автором проведен анализ отечественного и зарубежного опьта форм и способов поддержки и развития молодежного предпринимательства, выделены основные форматьл.

Ключевые слова: молодежь, мальй бизнес, культура, бизнес-инициативь, развитие молодежного предпринимательства, проблемы бизнеса.

Activities in the field of youth entrepreneurship are aimed at solving problems, first of all, socio-economic nature: reducing unemployment, realization of the possibility of creating new jobs, developing new directions and sectors of the economy, etc. Youth entrepreneurship is one of the factors in the development of the country's economy, so there is a need to attract young people to entrepreneurship. The article presents the modern scientific practice of youth entrepreneurship, which singled out some of its features, and also identified a number of strengths and weaknesses of this phenomenon. Based on the analysis, a retrospective of the positioning of young people in the modern business community is presented and the most important directions for improving this promising vector of national youth policy are formulated. The author of the analizo-otetstevennyh and zarubelnoye opit forms and methods of podderzhki and razvytyvay young predprinoytelstva, selected basic formats. The effectiveness these relations determines the need to take into account the phenomenon of cross-cultural management in the construction of business relations. As a result of the globalization of the world economy, 
in which representatives of different cultures are involved, it is necessary to try to increase the range of business contacts in the world market, expand investments abroad, increase the overall culture when working in a cross-cultural environment, build an adaptive management system based on the study of the experience of the world's best companies. Cross-cultural skills include: understanding the nature of culture and the fact that culture affects human behavior in his workplace; understanding the differences between cultures; understanding how cultural factors affect the organization of structures, systems and priorities; the ability to introduce elements of one culture to another; understanding how deeply elements of one culture can be introduced into another, and vice versa. Contraindications in the work of the international manager is ethnocentrism, that is, the desire to "fit" representatives of one culture into their own framework and expect them to meet these norms of behavior.

Key words: young people, small business, culture, business-incisives, young prep, business problems.

Постановка проблеми. Сучасна молодь відчуває найбільшу потребу розвивати свої професійні навички в підприємництві, а також вдосконалювати особисті якості впевненість у собі, креативність, готовність ризикувати. Соціологічні опитування студентів, проведені в Україні, показують, що до 8\% 3 них думають про створення власного підприємства. I ця цифра набагато вища, ніж у західних країнах [1].

У зв’язку з цим підтримка суспільства і держави необхідна 3 того моменту, як молода людина зрозуміє, що хоче займатися власною справою. На даному етапі існують такі механізми підтримки, такі як семінари, тренінги та майстер-класи для тих, хто хоче відкрити власний бізнес. На майстер-класах бізнесмени обмінюються досвідом і радять новачкам, які хочуть знайти ідею для бізнесу.

Аналіз останніх досліджень і публікацій. Існує безліч статей та програмних документів, що розглядають проблеми залучення молоді до підприємницької діяльності. Фундамент у вирішенні окремих проблем в рамках цього питання заклали такі науковці, як Т. Збрицька, Ю. Щотова, А. Левченко, І. Думанська; теоретичні напрацювання у сфері розв'язання проблем зайнятості молоді здійснені представниками економічної науки, зокрема Е. Лібановою, А. Колотом, І. Демченко, М. Долішнім, В. Петюхом, О. Грішновою [1, с. 196].

Формулювання цілей статті. В умовах соціально-економічної нестабільності важливою сферою державного регулювання $є$ зайнятість населення, що є однією 3 його ключових життєвих потреб і є основним напрямком розвитку його соціального захисту. Сьогодні, коли повноцінний російський ринок праці тільки формується, необхідно негайно розробити і впровадити політику зайнятості, в якій зниження безробіття серед молоді є однією з пріоритетних цілей розвитку економіки.

У контексті соціально-ефективних стратегій подолання безробіття серед молоді перебуває в центрі уваги не лише держави, а й міжнародних організацій, а також наукового співтовариства. Це пов'язано з тим, що безробіття, як правило, вдарить по молоді сильніше, ніж інші вікові групи, і тому соціальна маргіналізація молоді є серйозною проблемою для будь-якого суспільства. Вищесказане визначає актуальність і необхідність більш поглиблених досліджень цієї залежності. Важливість запропонованого розділу вивчення проблем безробіття обумовлена ще й тим, що в Україні безробіття серед молоді залишається маловивченим економічним явищем. Можна нарахувати лише кілька спеціальних наукових досліджень, присвячених цьому питанню.

Виклад основного матеріалу дослідження. Щороку на ринок праці приходять випускники системи початкової, середньої та вищої професійної освіти, фахівці, які готові працювати. Найбільший вплив на кількість зайнятих в економіці мають випускники денної освіти. Загальна чисельність цієї категорії становить близько 1,5 млн. осіб щорічно.

Основним протиріччям, характерним для сучасного молодіжного ринку праці, $є$ розрив між трудовими претензіями молоді і можливостями їх задоволення. Оскільки 
молоді люди, здебільшого, не мають практичного досвіду роботи (або недостатньо), їх високі вимоги до заробітної плати ускладнюють пошук відповідної роботи.

На нашу думку, молодіжні трудові біржі та центри зайнятості молоді мають всіляко розвиватися в регіонах, в рамках яких мають проводитися ярмарки вакансій за участю установ та підприємств регіонів. Крім того, необхідно постійно просувати молодіжні ініціативи у сфері підприємництва, пов'язані зі створенням нових робочих місць. Але для цього потрібна серйозна державна підтримка, зокрема, у вигляді пільгового податкового режиму.

Регіональні органи влади та органи місцевого самоврядування повинні брати активну участь у підготовці та фінансуванні програм сприяння зайнятості молоді.

Почати власний бізнес в Україні непросто, особливо якщо ви молоді і недосвідчені. Початківця підприємця чекає безліч труднощів, серед яких високі витрати, конкуренція, необхідність прийняття відповідальних рішень. Однак перспектива реалізації власного проекту та отримання гідного доходу все ж має величезний вплив на активне середовище сучасної молоді.

Хто він - молодий бізнесмен? На це питання не можна відповісти однозначно. Це молодий чоловік у віці від 20 до 30 років, який самостійно організовує виробництво або просування будь-якого товару або послуги. Він працює на себе, може мати кілька магазинів, торговий комплекс, займатися будівництвом, утримувати кілька перукарень або салонів, відкривати і розвивати фітнес-клуб або він може облаштувати старий гараж біля будинку для майстерні і ремонтувати автомобілі або продавати товари в кіоску. Складно сформувати детальний портрет, є багато молодих підприємців абсолютно різних і з різними доходами. Так що в цілому опис досить загальний, але одне можна сказати твердо: молодий підприємець заробляє гроші самостійно і самостійно вирішує, що, де і коли йому потрібно робити.

Однак статистика дуже прозаїчна. За даними реєстраційних органів, тільки в Україні щодня з'являється понад 90 компаній. На жаль, немає даних про те, скільки з них припадають на молодіжний бізнес і скільки молодих бізнесменів досягають успіху, знаходячи свою нішу на сучасному ринку товарів і послуг. При цьому понад $90 \%$ громадян, які реєструються як фізичні особи-підприємці, починають і закривають свій бізнес у перший рік.

Останнім часом розвиток малого бізнесу став одним з провідних напрямків у формуванні економічних відносин в Україні. До недавнього часу значного збільшення кількості малих підприємств не спостерігалося. Однак поспішати з висновками не варто потрібно враховувати, що лідируючі позиції великих компаній i, як наслідок, жорстке лобіювання законів власниками провідних корпорацій не дозволяє розвиватися малому бізнесу, в тому числі молодіжному підприємництву. Власники авторитетних компаній побоюються збільшення кількості малого бізнесу, який може рости і ставати серйозними конкурентами. Але варто відзначити, що тільки завдяки великому бізнесу України буде важко подолати економічні труднощі; економіці потрібні додаткові ресурси, які можна отримати за рахунок розвитку малих підприємств. Адже частина національного продукту створюється не на монополістичних корпораціях, а на малому бізнесі (у розвинених країнах частка ВВП, створеного малими підприємствами, становить більше половини; але від таких результатів ми ще далекі). Крім того, саме цей сектор економіки вирішує найважливіші соціально-економічні завдання держави.

Однією з вагомих причин нинішньої стагнації малого бізнесу є відсутність доступу до фінансових ресурсів і неефективність існуючих фінансово-кредитних механізмів. Молоді підприємці намагаються поліпшити ситуацію, спираючись на власну ініціативу і підприємництво. Але допомоги від держави вони поки не бачать: наразі в Херсонській області немає регіональних програм чи інших механізмів фінансової підтримки молодих підприємців та малого бізнесу загалом. 
Вважається, що бізнес спочатку є ризиком і якщо ви не хочете ризикувати, то йдіть і працюйте на ставку, як і всі інші. У силах Агентства регіонального розвитку було небагато: дати основи знань для відкриття і ведення власного бізнесу, а також практику створення бізнес-плану за моделлю полотна. Ці завдання лягли в основу проекту «Розвиток МСП Таврійського регіону через підтримку молодіжного підприємництва та покращення інформаційного середовища». Фінансування для проведення дводенних тренінгів в Каховці, Бериславі та Новій Каховці отримали від Програми USAID ЛЕB, яка реалізується Фондом Східна Європа та партнерами, членами партнерської мережі.

Багато в чому успішний розвиток малого бізнесу залежить від діяльності державних структур, як виконавчих, так і законодавчих. Державні органи, на які покладено розвиток малого бізнесу, повинні виконувати дві функції: забезпечення та управління. Функція забезпечення пов'язана з наданням фінансової підтримки малим підприємствам, інформаційним ресурсам, державним замовленням тощо. Функція управління стосується планування, оперативного управління, контролю. Реалізація цієї схеми повинна забезпечити стійкість і ефективність розвитку малого бізнесу.

Цільова державна підтримка малого бізнесу є надзвичайно важливою для перехідної економіки України, оскільки, як зазначалося вище, конкурентоспроможна на міжнародному рівні національна економіка фактично не може існувати без ефективно функціонуючого малого бізнесу. У нинішніх умовах, коли інфляція і відсутність позикового капіталу є ще більш серйозними проблемами для малого бізнесу, ніж для великих підприємств, така підтримка особливо важлива.

Формально державна підтримка малого бізнесу вже кілька років визнана в урядових документах одним з основних напрямків економічної реформи. Вона повинна сприяти розвитку конкуренції, заповненню споживчого ринку товарами і послугами, створенню нових робочих місць, формуванню широких верств власників і підприємців. Основними цілями має стати залучення молоді до підприємництва та об'єднання молодих підприємців для більш успішного бізнесу.

Висновки. Головне питання, яке виникає одразу: чи потрібні спеціальні форми підтримки молодих підприємців, і якщо так, то якими вони повинні бути? Зараз головна проблема в тому, що в нашій країні відсутня комплексна система підтримки молодих людей, які прагнуть реалізувати себе у сфері бізнесу. Мається на увазі інформаційна, методична та освітня складова, орієнтована на практичні навички підприємницької діяльності. Необхідно створити нормальні умови для формування і зростання підприємств, щоб вони були конкурентоспроможними, щоб впроваджувалися інновації. Для розвитку і підтримки молодіжного підприємництва в Україні необхідно створити комплексний підхід до вирішення цієї проблеми: законодавчо закріпити цілі і завдання молодіжного підприємництва. 3 метою підтримки та допомоги молоді - відкривати нові бізнес-інкубатори, сприяти створенню бізнес-інкубаторів в університетах. Необхідно залучати молодь до сфери підприємництва, адже саме молодіжне підприємництво $є$ фактором розвитку економіки країни.

Реалізація таких заходів $є$ прямим вкладенням держави та регіонів у майбутнє та може забезпечити посилення соціального захисту не лише молоді, а й сприяти розвитку соціального захисту інших категорій безробітних.

Для продуктивної співпраці молодіжного бізнесу та некомерційних або благодійних проектів рекомендується організувати діалогову платформу для обміну досвідом у сфері некомерційної діяльності. Такі платформи дозволяють нам вибудувати діалог не тільки всередині бізнес-спільноти, а й між підприємцями та некомерційними проектами. Разом вони могли б сформулювати і розробити стратегії взаємодії, засновані на поточних проблемах та існуючих рішеннях. Крім того, такі платформи дозволять молодим підприємцям дізнатися про позитивні бізнес-кейси для розвитку, а також про додаткові можливості для розвитку підприємницьких проектів через включення в некомерційну діяльність. 


\section{Список використаних джерел:}

1. Думанська І.Ю. Молодіжне інноваційне підприємництво як національна доктрина модернізації економіки. Вісник Хмельницького начіонального університету. Економічні науки. 2013. № 4. T. 2. C. 194-200.

2. Левченко А.О., Янішевська А.В. Молодіжне підприємництво - перспективний шанс для молодих спеціалістів. Наукові пращі КНТУ. Економічні науки. 2009. № 15. С. 52-56. URL: http://nbuv.gov.ua/UJRN/Npkntu_e 2009_15_10 (дата звернення: 01.08.2021).

3. Капліна А.І. Молодіжне підприємництво: проблеми та шляхи їх вирішення. Ефективна економіка. 2020. № 11. URL: http://www.economy.nayka.com.ua/?op=1\&z=8312 (дата звернення: 01.08.2021). DOI: $10.32702 / 2307-2105-2020.11 .50$.

4. Капліна А. І. Молодіжне підприємництво - перспективний шанс для молоді. Агросвіт. 2020. № 19-20. C. 47-50. DOI: 10.32702/2306-6792.2020.19-20.47.

5. Капліна А.І. Крос-культурний менеджмент як інструмент організації крос-культурної взаємодії. Агросвіт. 2020. № 21. C. 49-52. DOI: 10.32702/2306-6792.2020.21.49.

6. Капліна А.І., Кириченко Н.В. Крос-культурні аспекти управління персоналом. Ефективна економіка. 2020. № 10. URL: http://www.economy.nayka.com.ua/?op=1\&z=8258 (дата звернення: 01.08.2021). DOI: 10.32702/2307-2105-2020.10.58.

\section{References:}

1. Dumanska I.Yu. (2013) Molodizhne innovatsiine pidpryiemnytstvo yak natsionalna doktryna modernizatsii ekonomiky [Youth innovation entrepreneurship as a national doctrine of modernization of the economy]. Bulletin of Khmelnitsky National University. Economic sciences, vol. 4, no. 2, pp. 194-200.

2. Levchenko A.O., Janishevska A.V. (2009) Molodizhne pidpryiemnytstvo - perspektyvnyi shans dlia molodykh spetsialistiv [Youth entrepreneurship is a promising chance for young professionals]. Scientific works of KNTU. Economic sciences, vol. 15, pp. 52-56. Available at: http://nbuv.gov.ua/ UJRN/Npkntu_e_2009_15_10 (accessed 01 August 2021).

3. Kaplina A.I. (2020) Molodizhne pidpryiemnytstvo: problemy ta shliakhy yikh vyrishennia [Youth entrepreneurship: problems and ways to solve them]. Efficient economy, vol. 11. Available at: http://www.economy.nayka.com.ua/?op $=1 \& \mathrm{z}=8312$ (accessed 01 August 2021). DOI: 10.32702/2307-2105-2020.11.50.

4. Kaplina A.I. (2020) Molodizhne pidpryiemnytstvo - perspektyvnyi shans dlia molodi [Youth entrepreneurship is a promising chance for young people]. Agrosvit, vol. 19-20, pp. 47-50. DOI: 10.32702/2306-6792.2020.19-20.47.

5. Kaplina A. I. (2020) Kros-kulturnyi menedzhment yak instrument orhanizatsii kros-kulturnoi vzaiemodii [Cross-cultural management as an instrument of organization of cross-cultural interaction]. Agrosvit, vol. 21, pp. 49-52.

6. Kaplina A., Kyrychenko N. (2020) Kros-kulturni aspekty upravlinnia personalom [Cross-cultural aspects of human resources management]. Efektyvna ekonomika, vol. 10. 